\title{
Exploring the Benzimidazole Ring as a Substitution for Indole in Cannabinoid Allosteric Modulators
}

Laura Hernandez-Folgado, ${ }^{1, *}$ Lesley A. Stevenson, ${ }^{2}$ Paula Morales, ${ }^{1}$ María Gómez-Cañas, ${ }^{3-5}$ María Ruth Pazos, ${ }^{3-5}$ Maria Grazia Cascio, ${ }^{2}$ Nadine Jagerovic, ${ }^{1}$ José Elguero, ${ }^{1}$ Roger Pertwee, ${ }^{2}$ and Pilar Goya ${ }^{1}$

\begin{abstract}
Introduction and Objectives: The traditional approach to target a particular receptor is to design compounds that bind to the same site as the endogenous ligand, the so-called "orthosteric site." However, recently the search has shifted to ligands that can interact with a different region of the receptor protein, the "allosteric site," since this approach offers potential pharmacological and therapeutic advantages. The aim of our work was to explore the benzimidazole heterocycle as a novel scaffold for cannabinoid allosterism.

Materials and Methods: We synthesized a series of novel benzimidazole-2-carboxamides, analogues of ORG27569, and performed their pharmacological characterization as $\mathrm{CB}_{1} \mathrm{R}$ allosteric modulators using competitive $\left[{ }^{3} \mathrm{H}\right]-\mathrm{CP} 55940$ and $\left[{ }^{35} \mathrm{~S}\right]-\mathrm{GTP} \gamma \mathrm{S}$ binding assays.

Results: The benzimidazoles $\mathbf{3}$ and $\mathbf{4}$ produced significant negative allosteric modulation (NAM) of CP55940 agonism at the mouse $C B_{1} R$, although are somewhat less potent than the $C B_{1} R$ allosteric cannabinoid ORG27569. Conclusions: Replacing the indole ring with a benzimidazole ring within the structure of ORG27569 abolished the binding of the resultant ligands to $\mathrm{CB}_{1} \mathrm{R}$, but the modulation on the agonist-induced GTP $\gamma S$ binding was maintained.
\end{abstract}

Keywords: $\mathrm{CB}_{1}$ receptor; allosteric modulators; benzimidazole; ORG27569

\section{Introduction}

The traditional approach to target a particular receptor involves designing compounds, agonists or antagonists, that bind to the same site as the endogenous ligand, the so-called "orthosteric site." However, recently, the search has shifted to ligands that can interact with a different region of the receptor protein, the "allosteric site," since this approach offers potential pharmacological and therapeutic advantages.

One possibility to overcome the limitations of the "traditional" cannabinoids, interacting with the orthosteric sites on cannabinoid receptors, is to look for compounds that can bind to a different (allosteric) site. ${ }^{2,3}$ However, only a very limited number of chemical structures have been investigated as potential allosteric cannabinoid ligands (including endogenous and synthetical allosteric modulators). ${ }^{4}$ Among them, worth mentioning are the indole carboxamides such as ORG27569 (Fig. 1), ORG27759, and ORG29647, ${ }^{5}$ and some derivatives of these compounds, ${ }^{6-9}$ the urea compound PSNCBAM$1^{10}$ and its recently published ${ }^{11}$ and patented ${ }^{12}$ analogs, or the cocaine-related structure RTI- $371 .^{13}$

\footnotetext{
${ }^{1}$ Instituto de Química Médica, CSIC, Madrid, Spain.

${ }^{2}$ Institute of Medical Sciences, University of Aberdeen, Aberdeen, Scotland, United Kingdom.

${ }^{3}$ Departamento de Bioquímica y Biología Molecular, Facultad de Medicina, Universidad Complutense de Madrid, Madrid, Spain.

${ }^{4}$ Centro de Investigación Biomédica en Red sobre Enfermedades Neurodegenerativas (CIBERNED), Madrid, Spain.

${ }^{5}$ Instituto Ramón y Cajal de Investigación Sanitaria (IRYCIS), Madrid, Spain.
}

*Address correspondence to: Laura Hernandez-Folgado, PhD, Instituto de Química Médica, CSIC, Juan de la Cierva 3, Madrid E-28006, Spain, E-mail: Ihernandez@iqm.csic.es

(c) Laura Hernandez-Folgado et al. 2016; Published by Mary Ann Liebert, Inc. This Open Access article is distributed under the terms of the Creative Commons License (http://creativecommons.org/licenses/by/4.0), which permits unrestricted use, distribution, and reproduction in any medium, provided the original work is properly credited. 

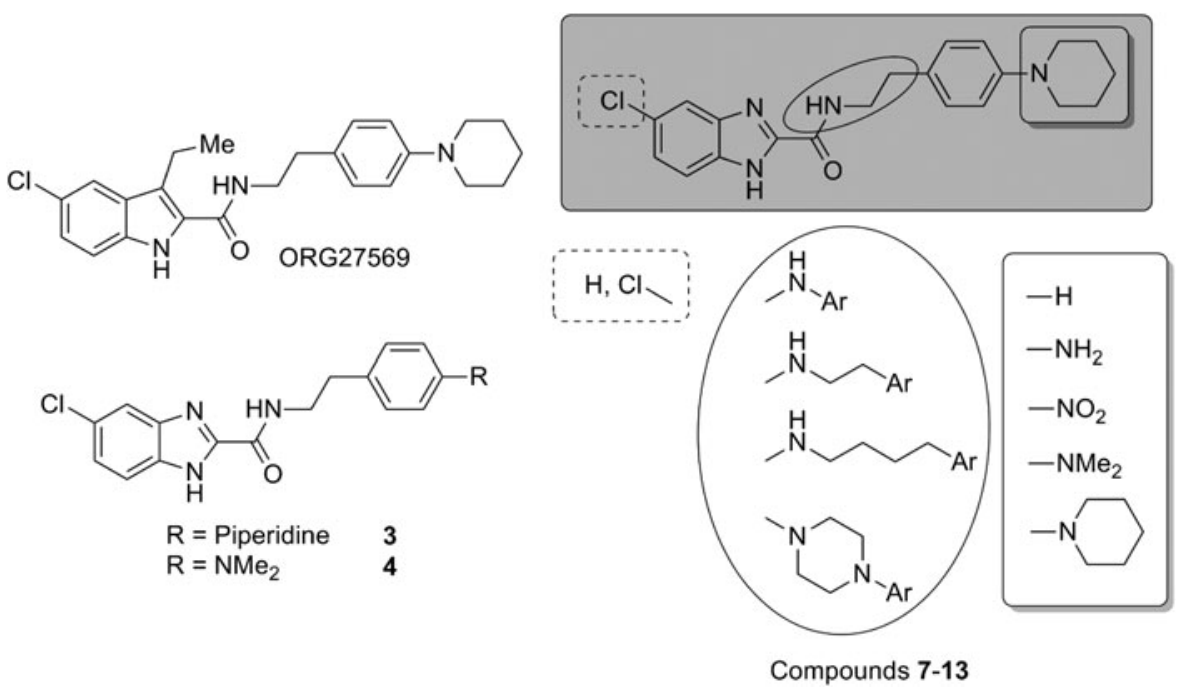

FIG. 1. Structure of ORG27569 and of the synthesized benzimidazoles.

Several analogs of ORG compounds have been extensively studied by Kendall, $\mathrm{Lu}$, and coworkers, ${ }^{7,14,15}$ but to date, the indole ring has not been replaced, with the exception of four benzofuran compounds, which had shown interesting properties. ${ }^{14}$ Within this context, we decided to study the possibility of modifying the nature of the heterocycle in the ORG compounds, incorporating a benzimidazole ring. To explore this scaffold, structural and substituent changes have been undertaken on the benzimidazole, on the piperidine group, and on the length of the amide linker (Fig. 1). Once synthesized, the affinity of the new compounds for $\mathrm{CB}_{1} \mathrm{R}$ and $\mathrm{CB}_{2} \mathrm{R}$ has been measured in competitive $\left[{ }^{3} \mathrm{H}\right]-\mathrm{CP} 55940$ binding experiments, and their efficacy as allosteric modulators has been evaluated in $\left[{ }^{35} \mathrm{~S}\right]-\mathrm{GTP} \gamma \mathrm{S}$ binding assays. Only compounds 3 and 4 showed some activity.

\section{Materials and Methods}

\section{Chemistry}

The synthesis of compounds $\mathbf{3}$ and $\mathbf{4}$ is described next. Preparation of compounds 5-13 was performed by a procedure similar to the one of compounds 1-4 (scheme and experimental synthetical details of compounds 5-13, and general synthetical issues are covered in the Supplementary Data).

\section{5-Chloro-2-(trichloromethyl)-1H-benzimidazole (1)}

Methyl trichloroacetimidate $(1.90 \mathrm{~mL}, 15.4 \mathrm{mmol}, 1.1$ equivalent [eq]) was added dropwise to a cooled solution of 4-chloro- $o$-phenylenediamine $(2.00 \mathrm{~g} ; 14.0 \mathrm{mmol}, 1$ eq.) in glacial acetic acid $(25 \mathrm{~mL})$. At the end of the addition, the dark reaction mixture was kept at room temperature for $1 \mathrm{~h}$. Afterward, water $(20 \mathrm{~mL})$ was added to facilitate the product precipitation. The resulting residue was filtered off, washed with water, and dried under vacuum. It was purified by mediumpressure chromatography (Isolera, eluent: hexane $\rightarrow 3: 7$ $n$-hexane/EtOAc) to give $3.05 \mathrm{~g}$ of $\mathbf{1}(80 \%)$ as a pale brown solid, mp: $231-233^{\circ} \mathrm{C}$. ${ }^{1} \mathrm{H}-\mathrm{NMR}(300 \mathrm{MHz}$, DMSO-d6): $\delta 7.73$ (bs, $\left.\mathrm{H}_{4}, 1 \mathrm{H}\right) ; 7.68$ (d, Jo= $8.5 \mathrm{~Hz}$, $\left.\mathrm{H}_{7}, 1 \mathrm{H}\right) ; 7.35$ (bd, Jo= $\left.8.5 \mathrm{~Hz}, \mathrm{H}_{6}, 1 \mathrm{H}\right) ;{ }^{13} \mathrm{C}-\mathrm{NMR}$ (75 MHz, DMSO-d6): $\delta 151.8 \mathrm{C}_{2} ; 139.1$ and 136.8 $\mathrm{C}_{3 \mathrm{a}}$ and $\mathrm{C}_{7 \mathrm{a}} ; 128.2 \mathrm{C}_{5} ; 124.3 \mathrm{C}_{6} ; 117.7$ and $116.1 \mathrm{C}_{4}$ and $\mathrm{C}_{7} ; 88.5 \mathrm{CCl}_{3}$; liquid chromatography/mass spectrometry (LC/MS) $(\mathrm{ES}+) t_{\mathrm{R}}=4.7 \mathrm{~min}(94 \%$ purity), $\mathrm{m} / \mathrm{z}=271[\mathrm{M}+\mathrm{H}]^{+}$.

\section{5-Chloro-1H-benzimidazole-2-carboxylic acid (2)}

$1(1.50 \mathrm{~g}, 55.6 \mathrm{mmol}, 1$ eq.) was added to a solution of sodium hydroxide $(100 \mathrm{~mL} ; 1 \mathrm{~N})$ at $0^{\circ} \mathrm{C}$. The resulting solution was filtered, and the filtrate was acidified with $37 \%$ hydrochloric acid to $\mathrm{pH} 4$. The precipitate was filtered off, washed twice with both water and ether. The resulting solid was then dried under vacuum to give $1.06 \mathrm{~g}(97 \%)$ of 2 as a pale brown solid, $\mathrm{mp}$ : 159$161^{\circ} \mathrm{C} .{ }^{1} \mathrm{H}-\mathrm{NMR}(300 \mathrm{MHz}, \mathrm{DMSO}-\mathrm{d} 6): \delta 8.28$ (s, $\mathrm{NH}, 1 \mathrm{H}) ; 7.66\left(\mathrm{~d}, \mathrm{~J} m=2.0 \mathrm{~Hz}, \mathrm{H}_{4}\right) ; 7.60(\mathrm{~d}, \mathrm{~J} o=8.6 \mathrm{~Hz}$, $\left.\mathrm{H}_{7}\right) ; 7.21\left(\mathrm{dd}, \mathrm{J} o=8.6 \mathrm{~Hz}, \mathrm{~J} m=2.0 \mathrm{~Hz}, \mathrm{H}_{6}\right) ;{ }^{13} \mathrm{C}-\mathrm{NMR}$ 
(75 MHz, DMSO-d6): $\delta 143.4 \mathrm{COOH}$ and $\mathrm{C}_{2} ; 139.3$ and $136.6 \mathrm{C}_{3 \mathrm{a}}$ and $\mathrm{C}_{7 \mathrm{a}} ; 126.2 \mathrm{C}_{5} ; 122.1 \mathrm{C}_{6} ; 116.4$ and $115.2 \mathrm{C}_{4}$ and $\mathrm{C}_{7} ; \mathrm{MS}(\mathrm{ES}+), \mathrm{m} / \mathrm{z}=197[\mathrm{M}+\mathrm{H}]^{+}$.

5-Chloro-N-[4-(piperidin-1-yl)phenethyl]-

$1 \mathrm{H}$-benzimidazole-2-carboxamide (3)

A mixture of 2 (192 mg, $1.0 \mathrm{mmol}, 1$ eq.), PyBOP (509 mg, $1.0 \mathrm{mmol}, 1$ eq.), and NMM (323 $\mu \mathrm{L}, 3.0 \mathrm{mmol}$, 1 eq.) in DMF $(3 \mathrm{~mL})$ was stirred at room temperature for $15 \mathrm{~min}$ to activate the acid. Then, 2-[4-(piperidin-1yl)phenyl]ethanamine hydrochloride $(270 \mathrm{mg}, 1.0 \mathrm{mmol}$, 1 eq.) was added and the mixture was stirred at room temperature overnight. Afterward, DMF was removed in vacuo. The residue was dissolved in EtOAc and washed with water $(3 \times 30 \mathrm{~mL})$. The organic layer was dried over anhydrous $\mathrm{MgSO}_{4}$, and the solvent was evaporated. The residue was purified by medium-pressure chromatography (Isolera, eluent: $n$-hexane $\rightarrow 3: 7$ hexane/EtOAc), obtaining 3 as a white solid (132 mg, 36\%), mp: $173-176^{\circ} \mathrm{C} .{ }^{1} \mathrm{H}-\mathrm{NMR}\left(300 \mathrm{MHz}, \mathrm{CDCl}_{3}\right)$ : $\delta$ 12.78-12.68 (m, Benzimidazole $\mathrm{NH}, 1 \mathrm{H}) ; 8.06$ (s, $\mathrm{CONH}, 1 \mathrm{H}) ; 7.75-7.29\left(\mathrm{~m}, \mathrm{H}_{4}, \mathrm{H}_{6}\right.$ and $\left.\mathrm{H}_{7}, 3 \mathrm{H}\right)$; 7.14 (d, $J=8.2 \mathrm{~Hz}, \mathrm{Hm}, 2 \mathrm{H}) ; 6.89$ (d, $J=8.2 \mathrm{~Hz}, \mathrm{Ho}$, $2 \mathrm{H})$; 3.84-3.74 (m, $\left.\mathrm{CONHCH}_{2}, 2 \mathrm{H}\right)$; 3.17-3.05 (m, piperidine $\left.\mathrm{NCH}_{2}, 4 \mathrm{H}\right) ; 2.93\left(\mathrm{t}, J=7.2 \mathrm{~Hz}, \mathrm{CH}_{2} \mathrm{Ar}\right.$, $2 \mathrm{H}$ ); $1.78-1.67$ (m, piperidine $\left.\mathrm{NCH}_{2} \mathrm{CH}_{2}, 4 \mathrm{H}\right) ; 1.60$ 1.52 (m, piperidine $\left.\mathrm{NCH}_{2} \mathrm{CH}_{2} \mathrm{CH}_{2}, 2 \mathrm{H}\right) ;{ }^{13} \mathrm{C}-\mathrm{NMR}$ $\left(75 \mathrm{MHz}, \mathrm{CDCl}_{3}\right): \delta 159.5 \mathrm{CONH} ; 151.0 \mathrm{Cp} ; 145.9$ $\mathrm{C}_{2} ; 143.7 \mathrm{C}_{3 \mathrm{a}} ; 141.5 \mathrm{C}_{3 \mathrm{a}}$ rotamer; $135.2 \mathrm{C}_{7 \mathrm{a}} ; 133.2 \mathrm{C}_{7 \mathrm{a}}$ rotamer; $130.7 \mathrm{C}_{5} ; 129.4 \mathrm{Co} ; 129.0$ Cipso; $125.6 \mathrm{C}_{6}$; $124.4 \mathrm{C}_{6}$ rotamer; $121.3 \mathrm{C}_{7} ; 120.2 \mathrm{C}_{7}$ rotamer; 117.1 $\mathrm{Cm} ; 113.6 \mathrm{C}_{4} ; 112.7 \mathrm{C}_{4}$ rotamer; 51.0 piperidine $\mathrm{NCH}_{2} ; 41.6 \mathrm{CONHCH}_{2} ; 35.0 \mathrm{CH}_{2} \mathrm{Ar} ; 25.9$ piperidine
$\mathrm{NCH}_{2} \mathrm{CH}_{2} ; 24.3$ piperidine $\mathrm{NCH}_{2} \mathrm{CH}_{2} \mathrm{CH}_{2} ; \mathrm{LC} / \mathrm{MS}$ $(\mathrm{ES}+) t_{\mathrm{R}}=2.9 \mathrm{~min}$ (99\% purity), $\mathrm{m} / \mathrm{z}=383[\mathrm{M}+\mathrm{H}]^{+}$.

\section{5-Chloro- $N$-[4-(dimethylamino)phenethyl]-}

$1 \mathrm{H}$-benzimidazole-2-carboxamide (4)

A mixture of 2 (60 mg, $1.0 \mathrm{mmol}, 1$ eq.), PyBOP (158 mg, $1.0 \mathrm{mmol}, 1$ eq.), and NMM (100 $\mu \mathrm{L}, 3.0 \mathrm{mmol}, 1$ eq.) in DMF $(3 \mathrm{~mL})$ was stirred at room temperature for $15 \mathrm{~min}$ to activate the acid. Then, 4-(2-aminoethyl)$\mathrm{N}, \mathrm{N}$-dimethylaniline $(50 \mathrm{mg}, 1.0 \mathrm{mmol}, 1$ eq.) was added and the mixture was stirred at room temperature overnight. Afterward, water $(30 \mathrm{~mL})$ was added to the reaction mixture. Then, the solid was filtered off, washed with water, and dried under vacuum, obtaining 4 as a brown solid (61 mg, $58 \%)$, mp: $187-192^{\circ} \mathrm{C} .{ }^{1} \mathrm{H}-$ NMR $\left(300 \mathrm{MHz}, \mathrm{CDCl}_{3}\right.$ ): $\delta 12.83$ (bs, Benzimidazole $\mathrm{NH}, 1 \mathrm{H}) ; 8.11$ (bs, CONH, $1 \mathrm{H}) ; 7.75-7.45$ ( $\mathrm{m}, \mathrm{H}_{4}$ and $\left.\mathrm{H}_{7}, 2 \mathrm{H}\right) ; 7.32-7.28\left(\mathrm{~m}, \mathrm{H}_{6}, 1 \mathrm{H}\right) ; 7.13(\mathrm{~d}, J=8.2 \mathrm{~Hz}$, $\mathrm{Ho}, 2 \mathrm{H}) ; 6.68(\mathrm{~d}, J=8.2 \mathrm{~Hz}, \mathrm{Hm}, 2 \mathrm{H}) ; 3.83-3.76(\mathrm{~m}$, $\left.\mathrm{CONHCH}_{2}, 2 \mathrm{H}\right) ; 2.95-2.86\left(\mathrm{~m}, \mathrm{CH}_{2} \mathrm{Ar}\right.$ and $\mathrm{NMe}_{2}$, $8 \mathrm{H}) ;{ }^{13} \mathrm{C}-\mathrm{NMR}\left(75 \mathrm{MHz}, \mathrm{CDCl}_{3}\right): \delta 159.5 \mathrm{CONH}$; 149.6 Cp; $146.1 \mathrm{C}_{2} ; 129.5 \mathrm{Co} ; 126.3 \mathrm{Cipso} ; 113.3 \mathrm{Cm}$; $41.7 \mathrm{CONHCH}_{2} ; 40.9 \mathrm{NMe}_{2} ; 34.8 \mathrm{CH}_{2} \mathrm{Ar} ; \mathrm{LC} / \mathrm{MS}$ $(\mathrm{ES}+) t_{\mathrm{R}}=3.0 \min (92 \%$ purity $), \mathrm{m} / \mathrm{z}=343[\mathrm{M}+\mathrm{H}]^{+}$.

\section{Pharmacology}

Equilibrium binding assay. The equilibrium binding assays were performed as previously described. ${ }^{16}$

$\left.{ }^{35} \mathrm{~S}\right]-\mathrm{GTP} \gamma \mathrm{S}$ binding assay. $\quad$ CP55940 was purchased from Tocris (Bristol, United Kingdom), $\left[{ }^{35} \mathrm{~S}\right] \mathrm{GTP} \gamma \mathrm{S}$ $(1250 \mathrm{Ci} / \mathrm{mmol})$ from PerkinElmer (Seer Green, Buckinghamshire, United Kingdom), GTP $\gamma \mathrm{S}$ from Roche
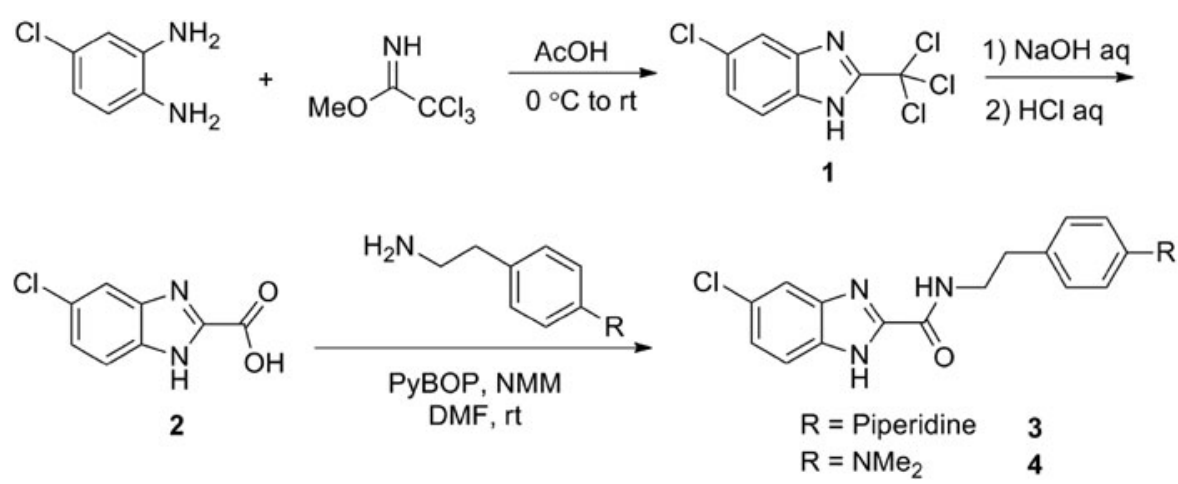

FIG. 2. Synthesis of benzimidazoles $\mathbf{3}$ and $\mathbf{4}$. 
Diagnostics (Burgess Hill, West Sussex, United Kingdom), and GDP from Sigma-Aldrich (Poole, Dorset, United Kingdom).

All $\left[{ }^{35} \mathrm{~S}\right]-\mathrm{GTP} \gamma \mathrm{S}$ binding assays were carried out with mouse whole-brain membranes, prepared as described elsewhere. ${ }^{17}$ These membranes ( $5 \mu \mathrm{g}$ of protein per well) were preincubated for $30 \mathrm{~min}$ at $30^{\circ} \mathrm{C}$ with adenosine deaminase $(0.5 \mathrm{U} / \mathrm{mL})$. The membranes were then incubated with the agonist with a vehicle or modulator for $60 \mathrm{~min}$ at $30^{\circ} \mathrm{C}$ in assay buffer $(50 \mathrm{mM}$ Tris- $\mathrm{HCl}, 50 \mathrm{mM}$ Tris-base, $5 \mathrm{mM} \mathrm{MgCl}_{2}, 1 \mathrm{mM}$ EDTA, $100 \mathrm{mM} \mathrm{NaCl}, 1 \mathrm{mM}$ dithiothreitol, and $0.1 \% \mathrm{BSA}$ ) in the presence of $0.1 \mathrm{nM}\left[{ }^{35} \mathrm{~S}\right]-$ GTP $\gamma$ S and $30 \mu \mathrm{M}$ GDP, in a final volume of $500 \mu \mathrm{L}$. Binding was initiated by the addition of $\left[{ }^{35} \mathrm{~S}\right]-\mathrm{GTP} \gamma \mathrm{S}$. Nonspecific binding was measured in the presence of $30 \mu \mathrm{M}$ GTP $\gamma$ S. The reaction was terminated by rapid vacuum filtration $(50 \mathrm{mM}$ Tris- $\mathrm{HCl}, 50 \mathrm{mM}$ Tris-base, and $0.1 \%$ BSA) using a 24-well sampling manifold (Brandel cell harvester) and GF/B filters that had been soaked in buffer $(50 \mathrm{mM}$ Tris- $\mathrm{HCl}, 50 \mathrm{mM}$ Tris-base, and $0.1 \% \mathrm{BSA}$ ) for at least $24 \mathrm{~h}$. Each reaction tube was washed six times with a $1.2-\mathrm{mL}$ aliquot of icecold wash buffer. The filters were oven-dried for at least $60 \mathrm{~min}$ and then placed in $3 \mathrm{~mL}$ of scintillation fluid (Ultima Gold XR). Radioactivity was quantified by liquid scintillation spectrometry.

\section{Results and Discussion}

The synthesis of compounds $\mathbf{3}$ and $\mathbf{4}$ is depicted in Figure 2. They were prepared by the coupling reaction of 5-chloro- $1 \mathrm{H}$-benzimidazole-2-carboxylic acid (2) with the corresponding amine in the presence of the PyBOP reagent and NMM in DMF. Acid 2 was obtained in good yield by hydrolyzing 5-chloro-2(trichloromethyl)-1H-benzimidazole (1) with sodium hydroxide aqueous solution, followed by acidification with dilute hydrochloric acid. ${ }^{18}$ In turn, 1 was first prepared from 4-chloro-o-phenylenediamine and trichloromethyl acetimidate using a weak acid.

The ability of benzimidazoles $\mathbf{3}$ and $\mathbf{4}$ to displace $\left[{ }^{3} \mathrm{H}\right]$-CP55940 from human cannabinoid $\mathrm{CB}_{1} \mathrm{R}$ or $\mathrm{CB}_{2} \mathrm{R}$ transfected into HEK293 EBNA cells was first evaluated at a compound concentration of $40 \mu \mathrm{M}$. At this concentration, none of the compounds was able to displace $\left[{ }^{3} \mathrm{H}\right]-\mathrm{CP} 55940$ from $\mathrm{CB}_{1} \mathrm{R}$ and/or from $\mathrm{CB}_{2} \mathrm{R}$ (data not shown). These data suggest that 3 and 4 could be discarded as orthosteric $\mathrm{CB}_{1} \mathrm{R} / \mathrm{CB}_{2} \mathrm{R}$ binders, since these compounds ( 3 and 4 ) did not affect the binding affinity of the cannabinoid receptor agonist CP55940 at $40 \mu \mathrm{M}$ $\left(K_{\mathrm{i}} \mathrm{CB}_{1} \mathrm{R}\right.$ and $\left.K_{\mathrm{i}} \mathrm{CB}_{2} \mathrm{R} \geq 40 \mu \mathrm{M}\right)$. Then, $\left[{ }^{35} \mathrm{~S}\right]-\mathrm{GTP} \gamma \mathrm{S}$
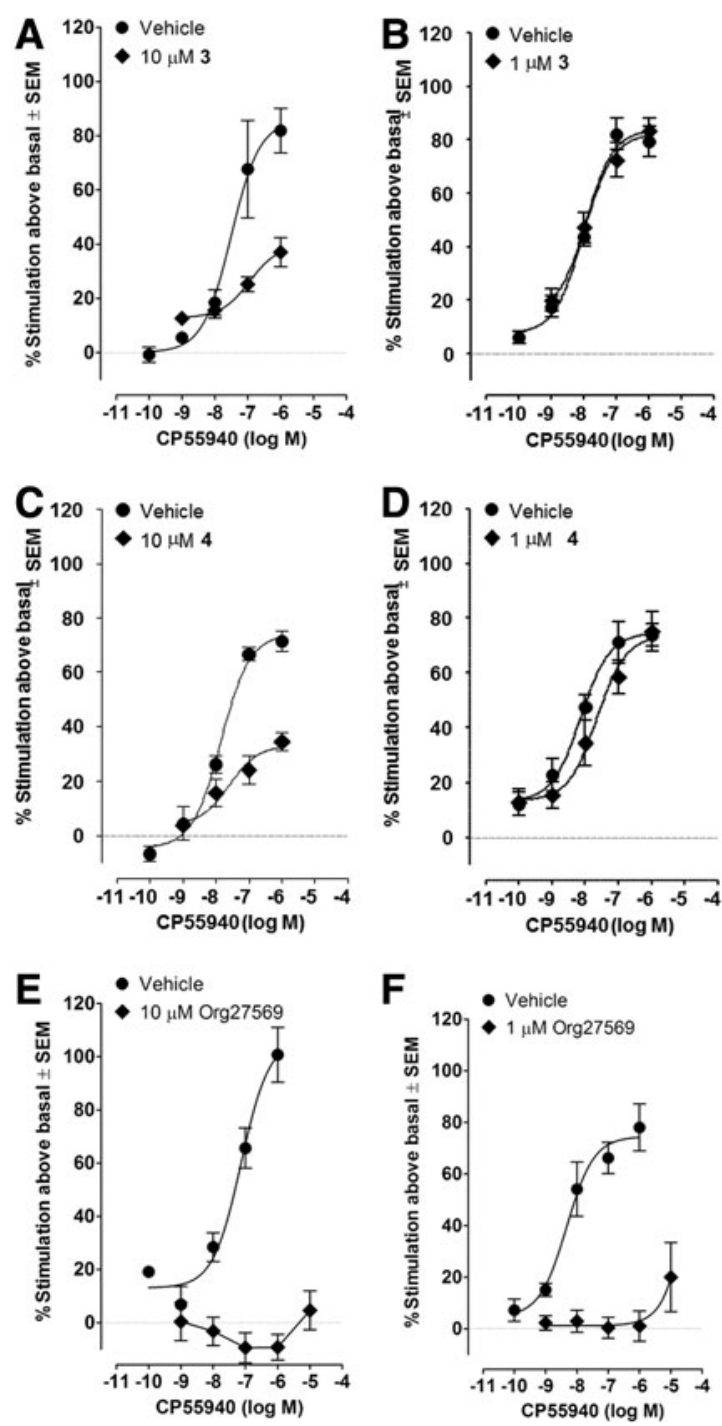

FIG. 3. Stimulation of binding of $\left[{ }^{35} \mathrm{~S}\right]-\mathrm{GTP} \gamma \mathrm{S}$ to mouse whole-brain membranes by CP55940 in the presence of vehicle (DMSO, $n=10$ ) or 3 at $10 \mu \mathrm{M}(n=10)(\mathbf{A})$, in the presence of vehicle (DMSO, $n=4)$ or 3 at $1 \mu \mathrm{M}(n=4)(\mathbf{B})$, in the presence of vehicle (DMSO, $n=4$ ) or 4 at $10 \mu \mathrm{M}$ $(n=4)(C)$, in the presence of vehicle (DMSO, $n=8)$ or 4 at $1 \mu \mathrm{M}(n=8)(D)$, in the presence of vehicle (DMSO, $n=4$ ) or ORG27569 at $10 \mu \mathrm{M}$ $(n=4)(E)$, and in the presence of vehicle (DMSO, $n=4)$ or ORG27569 at $1 \mu \mathrm{M}(n=4)(\mathbf{F})$. Each symbol represents the mean percentage stimulation above basal \pm SEM. 
binding assays in mouse whole-brain membranes were performed to assess the effect of the synthesized benzimidazoles on the functionality of CP55940.

In $\left[{ }^{35} \mathrm{~S}\right]-\mathrm{GTP} \gamma \mathrm{S}$ binding assays performed with compound 3 or its vehicle (Fig. 3A), CP55940 stimulated $\left[{ }^{35} \mathrm{~S}\right]-\mathrm{GTP} \gamma \mathrm{S}$ binding with a mean maximal effect $\left(E_{\max }\right)$ that was significantly less in the presence of 3 at $10 \mu \mathrm{M}(38.0 \%)$ than in its absence (70.2\%). The corresponding mean $\mathrm{EC}_{50}$ values of $\mathrm{CP} 55940$ in the presence and absence of 3 at $10 \mu \mathrm{M}$ were 118.4 and $16.9 \mathrm{nM}$, respectively, and these $\mathrm{EC}_{50}$ values are not significantly different from each other. In the case of compound 4 at $10 \mu \mathrm{M}$ (Fig. 3C), CP55940 stimulated $\left[{ }^{35} \mathrm{~S}\right]-\mathrm{GTP} \gamma \mathrm{S}$ binding with an $E_{\max }$ that was significantly less in the presence of $4(33.3 \%)$ than in its absence $(74.1 \%)$. The corresponding mean $\mathrm{EC}_{50}$ values of CP55940 are not significantly different from each other: $24.5 \mathrm{nM}$ in the presence of compound $\mathbf{4}$ and $14.1 \mathrm{nM}$ in its absence. However, at $1 \mu \mathrm{M}$, none of the compounds 3 and 4 affects the $\mathrm{E}_{\max }$, or indeed the $\mathrm{EC}_{50}$ of CP55940 (Fig. 3B, D, respectively). These results indicate that benzimidazoles $\mathbf{3}$ and $\mathbf{4}$ produce significant negative allosteric modulation (NAM) of CP55940 agonism at the mouse $\mathrm{CB}_{1} \mathrm{R}$, although they are somewhat less potent than the $\mathrm{CB}_{1} \mathrm{R}$ allosteric cannabinoid ORG27569, which showed efficacy on CP55940 at $1 \mu \mathrm{M}$ in this assay (Fig. 3F). The confidence intervals of these data are covered in the Supplementary Data (Supplementary Table S1).

According to the results from molecular modeling studies of the allosteric $\mathrm{CB}_{1} \mathrm{R}$ binding site of ORG27569 that have been published to date, the main interaction between this ligand and the receptor, in the presence of CP55940, occurs between the piperidine nitrogen and the K3.28(192) amino acid. ${ }^{19}$ However, there are not many reported data regarding the importance of the 3ethyl substituent or the free $\mathrm{NH}$ of the indole. Regarding the substitution on position 3 of the indole, a recent paper indicates that a small chain $(\mathrm{H}$ or $\mathrm{Me})$ improved $\mathrm{CB}_{1} \mathrm{R}$ allosteric modulation. ${ }^{8}$ It is noteworthy that in our hands, replacement of the 3-ethyl group of ORG27569 with a nitrogen (in 3 and 4) affects the efficacy with which GTP $\gamma$ S binding is allosterically modulated. Therefore, we performed the alkylation of $\mathbf{3}$ and $\mathbf{4}$, leading to $\mathrm{N}$-substituted compounds in position 3 of the heterocycle (data not shown). These compounds did not exhibit any $\mathrm{CB}_{1} \mathrm{R}$ allosteric modulation in $\left[{ }^{35} \mathrm{~S}\right]-$ GTP $\gamma$ S assays (data not shown), thus indicating that the presence of a free $\mathrm{NH}$ in benzimidazoles seems to be crucial for $\mathrm{CB}_{1} \mathrm{R}$ allosteric modulation.

\section{Conclusions}

In summary, the benzimidazole ring has been explored as a potential scaffold for developing cannabinoid allosteric ligands. Thus, a series of benzimidazole-2carboxamides has been prepared. Regarding binding assays, compounds $\mathbf{3}$ and $\mathbf{4}$ significantly attenuated the ability of CP55940 to stimulate $\left[{ }^{35} \mathrm{~S}\right]-\mathrm{GTP} \gamma \mathrm{S}$ binding, without affecting the orthosteric ligand binding affinity of [ $\left.{ }^{3} \mathrm{H}\right]-\mathrm{CP} 55940$ in radioligand competitive assays, suggesting that they may act as $\mathrm{CB}_{1} \mathrm{R}$ negative allosteric modulators. In conclusion, replacement of the indole ring with a benzimidazole ring within the structure of ORG27569 abolished the binding of the resultant ligands to $\mathrm{CB}_{1} \mathrm{R}$, but the modulation on the agonist-induced GTP $\gamma \mathrm{S}$ binding was maintained.

\section{Acknowledgments}

The authors gratefully acknowledge research support from Spanish Grant SAF2012-400075-C02-02 and CAM S2010/BMD-2308. P.M. is recipient of a fellowship JAE-Pre-2010-01119 from "Junta para la Ampliación de Estudios" that is co-financed by FSE.

\section{Author Disclosure Statement}

No competing financial interests exist.

\section{References}

1. Langmead CJ, Christopoulos A. Functional and structural perspectives on allosteric modulation of GPCRs. Curr Opin Cell Biol. 2014;27:94-101.

2. Ross RA. Allosterism and cannabinoid CB1 receptors: the shape of things to come. Trends Pharmacol Sci. 2007;28:567-572.

3. Khajehali E, Malone DT, Glass M, et al. Biased agonism and biased allosteric modulation at the CB1 cannabinoid receptor. Mol Pharmacol. 2015;88:368-379.

4. Morales P, Goya P, Jagerovic N, et al. Allosteric modulators of the CB1 cannabinoid receptor: a structural update review. Cannabis Cannabinoid Res. 2016;1:22-30.

5. Price MR, Baillie GL, Thomas A, et al. Allosteric modulation of the cannabinoid CB1 receptor. Mol Pharmacol. 2005;68:1484-1495.

6. Piscitelli F, Ligresti A, La Regina G, et al. Indole-2-carboxamides as allosteric modulators of the cannabinoid CB1 receptor. J Med Chem. 2012;55:5627-5631.

7. Khurana L, Ali HI, Olszewska T, et al. Optimization of chemical functionalities of indole-2-carboxamides to improve allosteric parameters for the cannabinoid receptor 1 (CB1). J Med Chem. 2014;57:3040-3052.

8. Nguyen T, German N, Decker AM, et al. Structure-activity relationships of substituted $1 \mathrm{H}$-indole-2-carboxamides as $\mathrm{CB} 1$ receptor allosteric modulators. Bioorg Med Chem. 2015;23:2195-2203.

9. Greig IR, Ross RA, Pertwee RG. et al. N-(Arylalkyl)-1H-indole-2-sulfonic acid amide compounds and their therapeutic use as cannabinoid allosteric modulators. 2012:WO2012117216.

10. Horswill JG, Bali U, Shaaban S, et al. PSNCBAM-1, a novel allosteric antagonist at cannabinoid $\mathrm{CB} 1$ receptors with hypophagic effects in rats. Br J Pharmacol. 2007;152:805-814.

11. German N, Decker AM, Gilmour BP, et al. Diarylureas as allosteric modulators of the cannabinoid $C B 1$ receptor: structure-activity relationship studies on 1-(4-chlorophenyl)-3-\{3-[6-(pyrrolidin-1-yl)pyridin-2yl]phenyl\}urea (PSNCBAM-1). J Med Chem. 2014;57:7758-7769.

12. Thakur GA, Tichkule RB, Kulkarni PM, et al. Preparation of bisaryl ureas as allosteric modulators of the cannabinoid 1 receptor. 2015: WO2015027160. 
13. Navarro HA, Howard JL, Pollard GT, et al. Positive allosteric modulation of the human cannabinoid (CB1) receptor by RTI-371, a selective inhibitor of the dopamine transporter. Br J Pharmacol. 2009;156:1178-1184.

14. Mahmoud MM, Ali HI, Ahn KH, et al. Structure-activity relationship study of indole-2-carboxamides identifies a potent allosteric modulator for the cannabinoid receptor 1 (CB1). J Med Chem. 2013;56: 7965-7975.

15. Ahn KH, Mahmoud MM, Samala S, et al. Profiling two indole-2carboxamides for allosteric modulation of the CB1 receptor. J Neurochem. 2013;124:584-589.

16. Cumella J, Hernández-Folgado L, Girón R, et al. Chromenopyrazoles: nonpsychoactive and selective $\mathrm{CB} 1$ cannabinoid agonists with peripheral antinociceptive properties. ChemMedChem. 2012;7:452-463.

17. Thomas A, Ross RA, Saha B, et al. 6"-Azidohex-2"-yne-cannabidiol: a potential neutral, competitive cannabinoid CB1 receptor antagonist. Eur J Pharmacol. 2004;487:213-221.

18. Louvet $P$, Lallement $G$, Pernot-Marino I, et al. Novel benzimidazoles as ligands for the strychnine-insensitive N-methyl-d-aspartate-linked glycine receptor. Eur J Med Chem. 1993;28:71-75.

19. Shore DM, Baillie GL, Hurst DH, et al. Allosteric modulation of a cannabinoid $G$ protein-coupled receptor: binding site elucidation and relationship to G protein signaling. J Biol Chem. 2014;289:5828-5845.
Cite this article as: Hernandez-Folgado $L$, Stevenson LA, Morales $P$ Gómez-Cañas M, Pazos MR, Cascio MG, Jagerovic N, Elguero J, Pertwee R, Goya P (2016) Exploring the benzimidazole ring as a substitution for indole in cannabinoid allosteric modulators, Cannabis and Cannabinoid Research 1:1, 196-201, DOI: 10.1089/can.2016.0003.

\section{Abbreviations Used}

$\mathrm{CB}_{1} \mathrm{R}=$ cannabinoid 1 receptor

$\mathrm{CB}_{2} \mathrm{R}=$ cannabinoid 2 receptor

$\mathrm{DMF}=$ dimethylformamide

$\mathrm{DMSO}=$ dimethylsulfoxide

$\mathrm{LC} / \mathrm{MS}$ = liquid chromatography/mass spectrometry

$\mathrm{NAM}=$ negative allosteric modulator

$\mathrm{NMM}=\mathrm{N}$-methylmorpholine

$\mathrm{PyBOP}=$ benzotriazol-1-yl-oxytripyrrolidinophosphonium hexafluorophosphate

$\mathrm{SEM}=$ standard error of the mean

\section{Publish in Cannabis and Cannabinoid Research}

Cannabis and

Cannabinoid

Research
- Immediate, unrestricted online access

- Rigorous peer review

- Compliance with open access mandates

- Authors retain copyright

- Highly indexed

- Targeted email marketing 